\title{
Research on Way and Strategy of Culture for Language Spread under Background of the Belt and Road Initiative
}

\author{
Yi Xiaohui \\ (Nanchang Institute of Science and Technology, Nanchang 330108)
}

\begin{abstract}
Keywords: The belt and road initiative; Language spread; Way and strategy
\end{abstract}
\begin{abstract}
The Belt and Road Initiative is an important window of spread Chinese culture, is the historical continuation and expansion of the Maritime Silk Road. The Belt and Road Initiative has been given the new connotation and life by Chinese culture construction and spread in Africa. As a communication mean across languages, translation can promote the culture exchange, culture combination and mutual learning, and strengthen the public's beliefs and appreciation of China. The high-quality translators are needed to shoulder the historical mission for the construction of The Belt and The Road and Chinese culture spread. This paper explains the function of language in Chinese and foreign language communication and the construction and spread of Chinese culture in abroad under background of The Belt and Road Initiative — precise translation will help China take the initiative of culture construction, expand the spread channels of Chinese culture, create more cultural investment opportunities, upgrade the international image of China and promote our country's cultural influence.
\end{abstract}

\section{Introduction}

As the carrier and factor of culture in national development, language is a special form, even it can be considered as an important measure of a nation's comprehensive strength, i.e., strong language means strong national strength. History has proved that ancient Chinese has greatly influenced many languages of the surrounding countries with the civilization of Han and Tang dynasties, and a Chinese character cultural circle was formed. Relying on the strong national strength and economic strength of England and America, English transmitted the products carrying national culture and values to the world, and mastered the world discourse power. So language plays the role that it should not have in international intercourse, acted as a variety of roles a diplomat, a missionary and an exchange envoy. In recent years, China has demonstrated a strong momentum of economic development and highlighted its political influence as a big country. These have laid a good foundation for the fusion of language culture. The strategy of The Belt and Road Initiative is a comprehensive strategy to realize the international influence of China, and its aim is to realize "the all-around cooperation and a community ". "The all-around cooperation" refers to policy coordination, facilities connectivity, unimpeded trade, financial integration, and people-to-people bonds, in which, the first four are the means, the last is the aim. "A community" refers to building a community of shared interests, destiny and responsibility. Under background of The Belt and Road, this paper studies the culture spread way and strategy for language, and analyzes the strategy and way for the cultivation of intercultural communicative competence under new situations to give implications for cultivation of foreign language talents in China and serve the development of "The Belt and Road Initiative".

\section{Concept Formation and Mission of the Belt and Road Initiative}

On September 7, 2013, President Xi Jinping visited Nazarbayev University in Astana, the capital and the second largest financial center of Kazakhstan, and made a profound speech. In the landmark speech, with mention of his hometown Shaanxi Province and the beginning of the ancient silk road as the introductory remarks, President Xi Jinping opened the prelude of "The Belt and Road". Before the world, President Xi Jinping firstly proposed the innovative cooperation mode for joint construction and launched the Common Initiative of the Silk Road Economic Belt. In 2014, in 
APEC meetings, President Xi Jinping summarized the Silk Road Economic Belt and the 21st Century Maritime Silk Road Economic Belt as the Belt and Road.

People-to-people bonds is the social foundation of the Belt and Road. It is the nature of people-to-people bonds to realize the mutual recognition and harmonious coexistence between different cultures. People-to-people bonds refers to the exchange between different countries, regions and people. Its final aim is to realize the culture fusion. No people-to-people bonds, no culture fusion. If there is no people-to-people bonds, in history, any political concessions and multilateral economic cooperation are difficult to realize due to the lack of durable source power. Therefore, the power of culture should not be underestimated. In spite of no special culture strategy based on the Belt and Road is proposed by our country at national level, the culture strategy is necessary for the Belt and Road Initiative. From strategy, culture not only represents a kind of speech right but also be a symbol of a nation's comprehensive strength. For culture itself, culture spread way has its own rules to follow in fusion and changes.

\section{Necessity of Chinese and Foreign Language Fusion under Background of the Belt and Road Initiative}

Language Fusion Is Conductive to Trading and Cost Reduction. The concept of the Belt and Road is to build a large economically dynamic region crossing the Asia continent, the African continent and the Europe continent by promoting the mutual and multilateral cooperation between China and the countries along the routes and developing the economic cooperation partnership for multiple countries. Since reform and opening-up, China's foreign trade has developed remarkably. But various trade barriers still seriously influence China's foreign trade due to the lack of national identity. So the international effective and quick communication are very necessary for the realization of economic integration of the countries along the routes of the Belt and Road. At present, the languages and cultures of the countries along the routes of the Belt and Road still deffer significantly from Chinese language and culture. These languages and cultures have strong stability in history. It means that high communication costs will be caused by the trading and communication with these countries or regions.

Language Fusion Is Conductive to Political Accommodation and Improvement of Mutual Trust. In strategy of the Belt and Road, policy coordination refers to that active policy communication and strong political coordination \& cooperation should be realized between all the member countries to clear up misunderstanding and differences between member countries, promote the mutual understanding and trust, and lay a solid political foundation for friendly cooperation of member countries.

Language Fusion Is Conductive to Cultural Exchange and Opinion Communication. The Belt and Road Initiative is a cooperation initiative to link many groups and countries and connect multiple cultures. People-to-people bonds is a basis for trading and mutual political trust, and the basic foundation of success of this strategy. The culture recognition and people-to people bonds of the people of various countries can not be promoted without respect for history and fact and the continuous discovery and spread of fine cultural content and form identified by various countries. In history, Japan dispatched monks to China to learn the books and system. By learning Chinese, they introduced the document literature carrying the related system and etiquette culture to Japan. Finally, the cultural identity and people-to-people bonds were promoted between China and Japan.

\section{Analysis of Way of Culture for Language Spread Under Background of The Belt and Road Initiative}

Innovation Development Strategy With Confucius Institute as the Platform. Relying on the platform of Confucius Institute, with the following two aspects as the starting point, a multidimensional and effective outlet terminal for culture spread with Chinese will be comprehensively built.

Teacher: the training base for teachers should be constructed, the cultivation for compound 
Chinese teachers should be strengthened, and the volunteer talent pool should be established. The specific measures include enlarging the enrollment scale of the major of teaching Chinese as a foreign language and the majors of non-English, expanding knowledge of the students of the major of teaching Chinese as a foreign language, properly adding the courses of literature, history and philosophy, encouraging students of the majors of humanities and social sciences to study the course of teaching Chinese as a foreign language as an elective course, and expanding the scope for volunteer selection. In addition, the teachers training for skilled worker should be added, because service export is also a kind of cultural exchange and learning.

Teaching material: the system of international Chinese textbook and teaching resources should be established and perfected. Regional and multilingual Chinese textbooks should be researched and developed relying on the colleges and universities with good base and high enthusiasm. By cooperating with presses at home and abroad, the textbook supply system with integration of compilation, publication and circulation should be established. The resource library of international Chinese textbook should be established to provide information service for teaching method research and textbook compilation. The international Chinese course standards and international Chinese textbook compilation guide should be prepared.

Promotion of Cultural Exchange and Spread With Language As the Link. The cultural exchange activities with various forms should be held such as "Chinese Bridge" and "Chinese Poetry Chanting". I think we can also promote the cultural exchange and spread by holding a series of Chinese culture promotion activities such as "Collection of Chinese Festivals", "Chinese Talents", "Chinese Food" and "Chinese Tradition Clothing Exhibition". The approachable activities are selected to hold some substantial exchange activities which make the people of the world appreciate them as their own favour. The scope should involve all the topics related to food, clothing, housing and transportation for people.

Way Analysis of Promoting Culture Spread for Overseas Chinese. With rapid population growth and greater population mobility in the world, immigration has become ever more a global phenomenon. To seek opportunities of job, high salary and education for himself and his children, to escape persecution and violence, tens and thousands of people go abroad each year. In some industrial countries, the proportion of non-citizens in the total population of the country is $5 \%$. Chinese is an important member of this immigration force. For the Chinese born and grew up abroad, in spite of that the component of Chinese culture is maintained in their culture gene, their culture identities must be changed to some extent due to acculturation of the local culture.

\section{Conclusion}

The strategy of The Belt and Road is a grand strategy for the realization of the Chinese dream. It adapts to the inevitable trend of economic and cultural globalization and accords with interests of the people of the world. Under the strategic background, the economic and cultural exchange between various nations will be more closer. In addition, the cultivation for talents with a certain kind of communicative language ability should be strengthened for culture spread with language. Under the new situations, according to requirements of The Belt and Road, we will convert ideas and actively explore new mode for cultivation of intercultural communicative competence from the aspects of cognition, emotion and behavior based on profound understanding of the connotation of intercultural communicative competence to provide sufficient intellectual support for the smooth implementation of The Belt and Road Initiative.

\section{References}

[1]Pilgun M A. Digital Russia: The Language, Culture and Politics of New Media Communication[J]. 2014.

[2]Coetzee S, Schmulian A, Kotze L. Communication Apprehension of South African Accounting Students: The Effect of Culture and Language[J]. Issues in Accounting Education, 2014.

[3]Parmaxi A, Zaphiris P. Computer-mediated communication in computer-assisted language 
learning: implications for culture-centered design[J]. Universal Access in the Information Society, 2016, 15(1):169-177.

[4]Temkina V L, Osiyanova O M, Tuchkova E Y, et al. Communication Situations as a Means of Verbal Communication Culture Formation in Foreign Language Learning[J]. Indian Journal of Science \& Technology, 2016, 9(16).

[5]Goettsch K L. Understanding Intercultural Communication on Global Virtual Teams: Exploring Challenges of Language, Culture, Technology, and Collaboration[J]. Dissertations \& Theses Gradworks, 2014.

[6]Jäger L, Krapp P, Holly W, et al. Sprache - Kultur - Kommunikation / Language - Culture Communication[M]. De Gruyter, 2016.

[7]Gibbs J L, Grushina S V, Gibson C B, et al. Encouraging participation in global teams: Unpacking the role of language, culture, and communication practice[J]. 2013.

[8]Mcgregor W B. Culture, Interaction and Person Reference in an Australian Language: An Ethnography of Bininj Gunwok Communication by Murray Garde (review)[J]. Anthropological Linguistics, 2016, 57.

[9]Gao H. On the Cultivation of Cross-culture Communication Competence of Second Language Learners[J]. Theory \& Practice in Language Studies, 2013, 3(8).

[10]Xianghong X U. The Promotion of Language and Culture in the Communication Perspective:Problems and Solutions:a Case Study of Confucius Institute[J]. Journal of Zhejiang Shuren University, 2017.

[11]Xianghong $\mathrm{X}$ U. The Promotion of Language and Culture in the Communication Perspective:Problems and Solutions:a Case Study of Confucius Institute[J]. Journal of Zhejiang Shuren University, 2017.

[12]Cheng Y. A primer on language, culture and communication[J]. Linguistics \& Education, 2018. 